RUTH DOROT

The School of Architecture

Ariel University

\title{
Mosaic of Israel's landscapes as an expression of geographical, cultural, and religious diversity
}

\begin{abstract}
Aвstract. Dorot Ruth, Mosaic of Israel's landscapes as an expression of geographical, cultural, and religious diversity. "Images" vol. XXV, no. 34. Poznań 2019. Adam Mickiewicz University Press. Pp. 87-113. ISSN 1731-450X. DOI 10.14746/i.2019.34.06.

Israel is tiny in its dimensions, yet huge in the spectrum of its landscapes. It is ancient in its history, yet young as a state. In honor of the $70^{\text {th }}$ independence day of the State of Israel, celebrated in 2018, this paper presents a mosaic of 12 landscape paintings, from the country's most southern point to the most northern one, by Israeli artists who represent, in diverse styles, the state's geographic and historic wealth in a visual-artistic sense.
\end{abstract}

KeYwords: Ludwig Blum, Michael Kovner, Baruch Nachshon, Reuven Rubin, Mordechai Ardon, Nachum Guttman, Oded Feingersh, Ron Gang, Larisa Bersky, Marcel Janco, Mordechai Levanon, Pamela Sharni

At the speed of $100 \mathrm{~km} / \mathrm{h}$, a car can traverse the length of Israel in, approximately, five hours. It will cross its maximum width in one hour. Despite its minute dimensions, Israel benefits from a broad diversity of landscapes, vegetation, flora and fauna, as well as climates: Temperatures range from the "infra" to the "ultra", from $45^{\circ} \mathrm{C}$ in the south in the summer to $-15^{\circ} \mathrm{C}$ in the north in the winter.

Israel, which celebrated its $70^{\text {th }}$ Independence Day in 2018, is the Promised Land that God bequeathed to Abraham: "I will establish my covenant as an everlasting covenant between me and you and your descendants after you for the generations to come, to be your God and the God of your descendants after you. The whole land of Canaan, where you now reside as a foreigner, I will give as an everlasting possession to you and your descendants after you; and I will be their God." (Genesis 17:7-8). This land is ancient and yet is at the apex of modern technological developments in the twenty-first century. In its 70 years of independence, Israel increased its population 14-fold, revived the nation's historical language - Hebrew - and at the same time, absorbed immigrants from 70 countries and languages. The country's cultural wealth and diversity encompass all areas of life.

The commandment "Thou shalt not make unto thee any graven image, or any likeness", which was erroneously interpreted to prohibit any figurative art, along with the hardships of Jewish existence in the Diaspora, diverted Jews from engaging in the arts, and the visual arts in particular. It was only in the $19^{\text {th }}$ century in the modern era that the
Images vol. XXV/no. 34

Poznań 2019

ISSN 1731-450X 
groundwork was laid for Jewish art in Europe, and indeed, "The roots of modern Israeli art lie in the art of European Jews in the $19^{\text {th }}$ century".[1] In 1906, the new Zionist settlers established the Bezalel Academy of Fine Arts in Jerusalem, headed by the Lithuanian-born Boris Shatz.

The immigrant artists were drawn to landscape painting. For the artists in the Land of Israel, and later on in modern Israel, engagement with landscapes has been an attempt to connect to one's roots, and to immerse oneself in the physical and human landscape in the sense expressed by poet Shaul Tschernikhovsky, "Man is but the imprint of his native homeland".

From its very start, the Israeli art establishment was dominated by two main trends: the local oriental influence on the one hand, and the international influence of mostly European modernism on the other. Inspired by the Bezalel Academy, the Orientalist paintings were peopled with shepherds and farmers, olive trees and "biblical hills," desert dunes and coastal sand that express a romantic yearning for the exotic magic of the Orient and its ancient biblical dimensions. As Gideon Ofrat noted: "The phenomenon known as Bezalel did not develop in an artistic wasteland. In Jerusalem, Safed, Haifa and other places, artists were living and modestly creating".[2] The modernist pioneering artists added the winds of modernism in the form of bold colors and lyrical brushstrokes and more specific forms of contemporary art movements, as some of them had established their artistic status as key figures in some of these movements. As time passed, the influence of modernist culture increased, and the school of Orientalism disappeared. After the establishment of Israel, the movement known as New Horizons introduced the domination of abstract art, and in later years, Israeli artists sought expression and recognition in the global art scene. "However, for the most part, art remained immersed in local influences and in the complex issues of Israeli identity, gender identity and the political situation".[3] According to the multidisciplinary artist Oded Feingersh: "In spite of our desire to be a part of the larger world and the 'global village', there is still a local cultural war between the romantic idealization of the land at the turn of the $2 \mathrm{O}^{\text {th }}$ century and the war over territory at its close. Despite the distance of decades, the paintings of stone terraces, olive trees, coastal sands and the rolling hills of Judea still constitute contemporary and local art, and are still a declaration".[4]

This paper presents a mosaic of 12 landscape paintings by Israeli artists, mostly immigrants, who represent the twelve tribes named after the sons of Jacob who inherited the Promised Land, each with his own territorial boundary. This mosaic offers the viewer not only rich and varied panoramas, but also a look at the fundamentals of Israeli art and the process the landscape genre has undergone, from a roman-

[1] Y. Zalmona, One Hundred Years of Israeli Art, Jerusalem 2015, p. 13.

[2] G. Ofrat, L. Dorit, The Story of Israeli Art, Ramat Gan 1991, p. 13.
[3] R. Forer, Israeli Painting: From Post Impressionism to Post Zionism, New York 1998, p. 10.

[4] O. Feingersh, Israeli Landscape (Exhibition Catalogue), Hulon 1989, p. 2. 
tic perspective to a more contemporary attitude in form and content. The selection of paintings offers an aesthetic and emotional mapping, as well as an artistic perspective on the country's terrain and its unique features.

The Negev covers more than half of Israel, over some $13,000 \mathrm{~km}$, or at least $55 \%$ of the country's land area. It forms an inverted triangle shape, the western side of

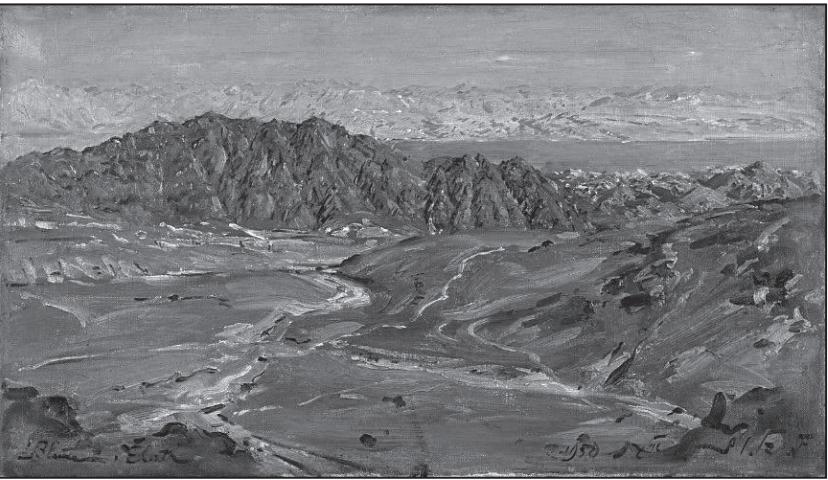
which is contiguous with the desert of the Sinai Peninsula, and whose eastern border is the Arabah valley. The Negev is a rocky desert. It is a mélange of brown, rocky, dusty mountains interrupted by dry riverbeds that bloom briefly after rain.

Ludwig Blum (1891-1975) is among the first of Israel's artists who was enchanted by the desert, with its vast, expansive, empty vistas. "Blum painted the land of Israel with great sensitivity to light and careful attention to color; the viewer can sense this sensitivity in the gentle gradations of the hues painted. The desert and the mountains enthralled him; put a spell on him".[5]

Blum had a European academic artistic education that embraced both a realism rooted in concentrated observation and an emotionally restrained expressionism. That last phrase might sound like an oxymoron, but it effectively captures Blum's focus on the harmony that he perceived and portrayed between earth and sky, the man-made world and nature.

Art historian Gideon Ofrat argues that Blum "recorded" reality as a documentary and remained faithful to it in an almost photographic manner. His precise and careful realistic, European style - the product of conservative Austrian impressionism - was a kind of middle way between academic tradition and expressionism,[6] characterized by light brushstrokes, but without the decomposition of form typical of poetic impressionists. Blum admitted, "I have never been enthusiastic about extreme abstract art. Even today I have misgivings about all the styles and streams in modern art".[7] Defining himself as a professional academic artist was a declaration connoting traditionalism, even conservatism. Aligning oneself with academic art, which was generally identified with nineteenth-century classicism, was a rejection of modern art as such.

Blum declared that he "reconstructed that which God had created".[8] In his view, the artist should reflect the beauty of the world, rather than express his own ideas, which vary with his mood and the state of his soul. Blum's loving, optimistic view of the landscapes of

[5] D. Manor, Pink Light: Ludwig Blum's Desert Paintings, Be'er Sheva 2014, p. 51.

[6] T. Binyamin, L. Dorit, O. Gideon, The Story of Art in Israel, Ben Shemen 1991, p. 90.
Fig. 1. Ludwig Blum, Mt. Shlomo and the Red Sea (1950), oil on canvas, $62.9 \times 78 \mathrm{~cm}$, private collection
[7] D. Manor, The Painting of Ludwig Blum, Tel Aviv, Beit Hatfutsot / The Museum of the Jewish People, 2009, p. 19.

[8] Ibidem. 
Israel and its people, typically bathed in a pinkish-orange glow, imbues everything he painted with human warmth.

As Blum sought out different facets of the landscape, he focused on the plastic forms of the rocks and the high skyline. A spectacular panorama of Mt. Shlomo (Solomon) on one side, the Jordanian mountains on the other, with the Red Sea between them, are depicted in Mt. Shlomo and the Red Sea (1950), in a rectangular composition that conveys the enormous expanse of the desert. These vistas erupt from the frame to continue in the observer's own imagination. The sense of dryness, parched thirst and yearning for an oasis are portrayed through the multiple shades of brown, beige, yellow, ochre and orange-pink. Sunlight washes over the entire view, adding to the artist's photograph-like credibility, especially through his naturalistic free brushstrokes and thick paint. The work showcases the artist's remarkable ability to capture the unique variegated desert light and motion of the shadows.

Behind the earth that craves to be quenched, two mountain ranges meet and merge. On the left, $M t$. Shlomo, made of magmatic rocks that were formed from the solidification of magma or lava, and metamorphic rocks, created from the chemical transformation of other rocks, stretches tautly before us. This is the source of its black color, being one of the highest and oldest mountains in the Eilat mountain range. Its name is traced to King Solomon, who dug mines on that site. A clear line separates the granite, an igneous rock, from the limestone, a sedimentary rock, which comprises the mountain. On the right is a lower mountain range in brown and pink. In the background of this range, a thin strip of the blue of the Red Sea intersects the stretch of desert, as the pink mountain range rises in the distance.

The refreshing Gulf of Eilat, in a deeper blue than the greenish-pinkish sky, is compensation for the very tangible aridity. The Jordanian mountains stretch from end to end on the horizon, depicted by Blum from a great distance, creating a frame that emphasizes the Israeli side of the border. The silence in the desert, the infinite expanse, the scorching heat, the hints of sparse human settlement, and a sense of secrecy captured in this ancient sight, all stimulate the observer's imagination.

The singularity of this painting is achieved through two aspects: firstly, the artist's close-up examination provides the observer with an extremely accurate sense of the place, and his observation from afar creates the sense that the landscape is unattainable.

Secondly, the meeting of two techniques: the one, whereby the artist's brush is almost unfettered, and the other, by means of which the precise details of every crevice, pit in the rocks and each ripple on the water, do not escape the artist's eye.

The appearance of the stream in the desert is highly unpredictable. The river's source is upon the slopes of the Ramon Crater - a geological feature located at the peak of Mount Negev, some $85 \mathrm{~km}$ south 
of the city of Beersheba - and it ends in the Dead Sea. The landscape is dramatic in places, with plunging canyons and meandering dusty paths, which cause small waterfalls and the water to ride over the bumpy, dusty terrain.

The waters of the river Zin are seen gushing down a dry riverbed. The return of the flood waters are because of heavy rain in mountainous regions several miles away from the arid land. It does not take long for a convincing stream that gushes down holes in the rock to appear, strengthening all the time.

Jerusalem-based Michael Kovner

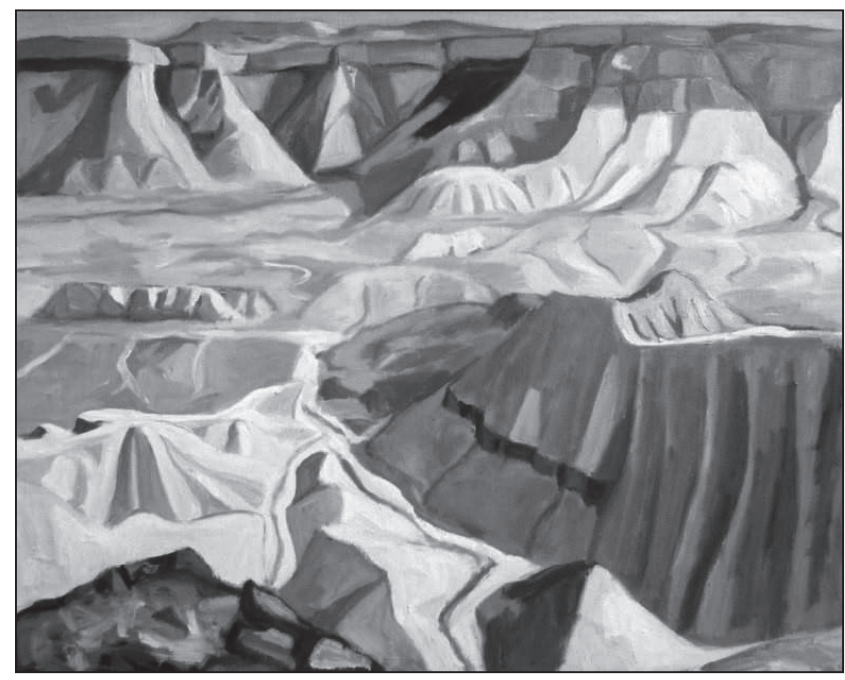
(b. 1948), who has frequently painted Israel's landscapes since the 1980s, captures the primordial and raw Zin Desert. Kovner stated that "The River Zin is the only place in Israel that is exclusively identified with the Zionist idea... it is the location chosen by David Ben Gurion as his burial place".[9]

Kovner traveled in the country to gain a feel of its geography and experience it through in-depth observation. His journey produced a series of 24 panoramic works - single, diptychs, and triptychs - influenced by Cezanne, Picasso, and cubism. He was familiar with each shadow, crevice and scar on the old faces of the architecturally sculpted cliffs, a familiarity comprising a part of his scientific approach to the study of the movements of the landscape while investigating the foundation of its creation. The expressive vistas forcefully declare their presence, reinforced vis-a-vis the artist, the lonely wanderer in the desert. Kovner personifies nature and grants it power, restraint and eternal tranquility. Still, alongside the absolute serenity lurks a sense of admiration-turned awe, originating from that power. The landscapes echo loneliness and yearning for the poems of his childhood and evoke memories of his late father, Holocaust survivor and poet Abba Kovner.

The painting Nahal Zin (The Zin Stream) (2008-2012), one of a series of panoramic works, began, as the others, in the artist's studio in Jerusalem and was concluded in nature, while Kovner was meditatively walking in the desert during the day and watching the falling stars at night. Kovner claimed that the landscape was "reflexive, a deep reflection of the soul, rather than beautiful, interesting or picturesque".[10] The primal, pre-civilization sight, described from above, is comprised of voluminous shapes that become geometric, flat and huge. This mode of observation causes the depicted object to approach a lyrical abstract form. Kovner's unique perspective of the landscape is not from within, but from a high, distant observation point, looking down at it. None-
[9] H. Maor, MaorArt, Michael Kovner - Across the
[10] Ibidem.

Cliff, <http://www.maorart.com/about-4>.

Fig. 2. Michael Kovner, Nahal Zin (The Zin Stream) (2008-2012), oil on canvas, $130 \times 150 \mathrm{~cm}$, Artist's collection 
theless, "It seems that he is not trying to capture the entirety, or flatten it, as it is captured in a satellite image, but he is more interested in what a bird in flight sees, gliding up and down, as its perspective changes in movement".[11]

The artist's loving approach towards the desert is a romantic one, according to his own testimony: "In my soul I am close to the German philosophers Hegel, Nietzsche, and Schopenhauer".[12] His affinity to a romantic perspective is reflected in his yearning for the ancient majesties and in his amazement at the primordial power of the forces of nature. It is in these that the "self" seeks itself through creation and seeks evidence of his own insignificance in comparison, as he converses in a metaphysical dialogue with the awe-filled universe.

As stated, the artist went to the desert as a romantic wanderer. The dimensions, the shifting weather conditions, the transitions between day and night, sunrises and sunsets, the variations in angles of vision, all of these prompted him to paint the series of cliffs underpinned with the brushstrokes of the greatest Impressionist, Claude Monet, yet his end result is different. The reason lies in Kovner's subjective attitude and the projection of his emotions and thoughts onto the landscape. His paintings contain the "dictatorship of the eye and the idea of the soul". According to the artist, "the dictatorship of the eye' refers to the artist's discipline regarding what his eye sees and what it dictates to him. That is a realistic painting - the product of direct observation of an object at a given time and place".[13] That is not enough for him, as he prefers to attach himself to "the idea of the soul" in order to let the soul "lead, carry, and grow wings". [14] Therefore, he adds colors that are not to be found in his surroundings. Contrasting with the powerful fauvist images, his vibrant colors are poetic, light-flooded and delicate, as his brushstrokes sensitively vibrate over the dominant pastel hues in Nahal $\mathrm{Zin}$, in which the colors are the product of a soul thrilled. He has the ability to draw hills, valleys, plains and trees as palpable tactile objects.

Despite his propinquity to the landscape - "I am part of nature, and nature is part of me" - Michael Kovner's ultimate conclusion is that it is impossible to merge with nature because these landscapes are "of the extreme - telling you: 'No further!"' [15] reminding one of Moses' tragedy on Mt. Nevoh, when he was barred from entering the promised land.

Hebron is one of the most ancient towns in the world, and it is considered one of the four towns in Israel that always had a Jewish population after the destruction of the Second Temple. The holy city of Hebron, the city of the nation's forefathers, features the Cave of the Patriarchs, situated in the center of the painting, which, according to the Torah was purchased by Abraham. Jewish tradition and scriptures

[11] I. Vizgan, exhibition: "Observations - Drawings of Landscapes", Jerusalem: The Jerusalem Artists' House, March 2010.

[12] H. Maor, MaorArt.
[13] Ibidem.

[14] Ibidem.

[15] Ibidem. 
hold that Adam and Eve were buried there, as were the nation's three patriarchs (Abraham, Isaac, and Jacob) and three of the nation's matriarchs (Sarah, Rebecca, and Leah; Rachel was buried in Bethlehem). Hence, the cave is a sacred site for Judaism and Islam.

Baruch Nachshon (1939) is a Habad Hassid who paints Hebron because of his close acquaintance with the place, his strong faith and residence in an adjacent town. His style is easily identified by the folkloristic-naïve-realistic element acquired from Shlomo Narny, a student of Paul Cezanne, the French post-Impressionist who influenced the birth of Cubism. Nachshon is also inspired by Persian and Indian art, as reflected in the tiny colorful mosaic-like and jewel-embedded forms. In his youth, the artist was a shepherd on the hills tending to his flocks, but later, he relinquished his flute, replacing it with a brush. His life was transformed

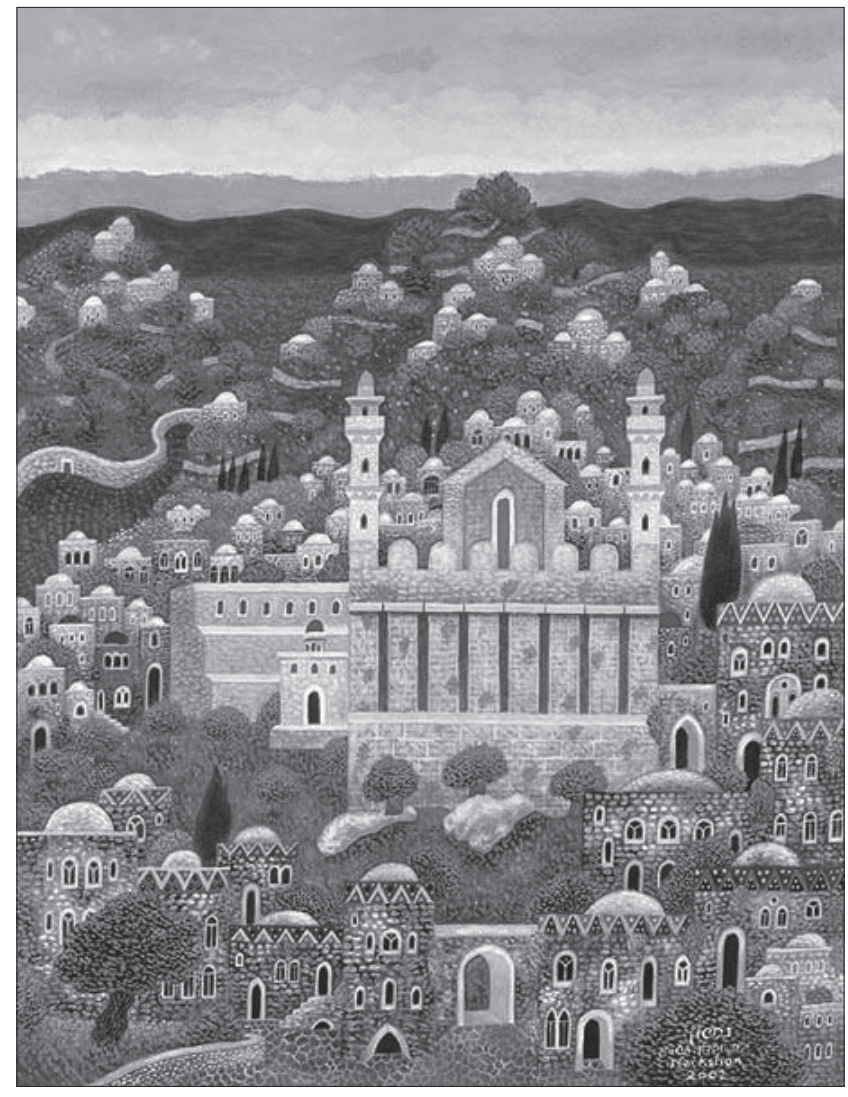
by a private three-hour meeting with the Lubavitcher Rabbi, which led to a scholarship to the School of Visual Arts in New York.

Baruch Nachshon's unique status as a Hassidic Jewish artist was also the inspiration for author Chaim Potok's book My Name is Asher Lev, which describes a Jewish orthodox boy who wishes to draw professionally. The narrative focuses on his inner struggles with the "impure" aspects of art, as he deliberates about the consequences of his decision affecting his family and his rabbi.

In his works, Nachshon translates stories from the Bible, rabbinical literature and visions of the prophets into the language of art. He seeks to create full harmony of colors and forms, and frequently uses Jewish motifs, such as the Temple, the seven-branched Menorah, candles, pomegranates and shofars made of rams' horns.

In the painting, Hebron's everyday reality is wrapped in an aura of a fairytale. The Cave of the Patriarchs merges classical, oriental, and imaginary stylistic elements. The remaining sections of the city are scattered among the refreshing greens, from which the cypress and almost-blue olive trees "peek and converse" with the blue sky above the brown hills stretching on the horizon. Cultivated agricultural plots, terraces on mountain slopes and ancient oriental local architecture with arches, domes and minarets, abound. The architecture in this work, surrounding the Cave, recalls crystals of precious stones planted among the olive trees and the vegetation.

Fig. 3. Baruch Nachshon, Hebron (2002), oil on canvas, $100 \times 65 \mathrm{~cm}$, private collection 


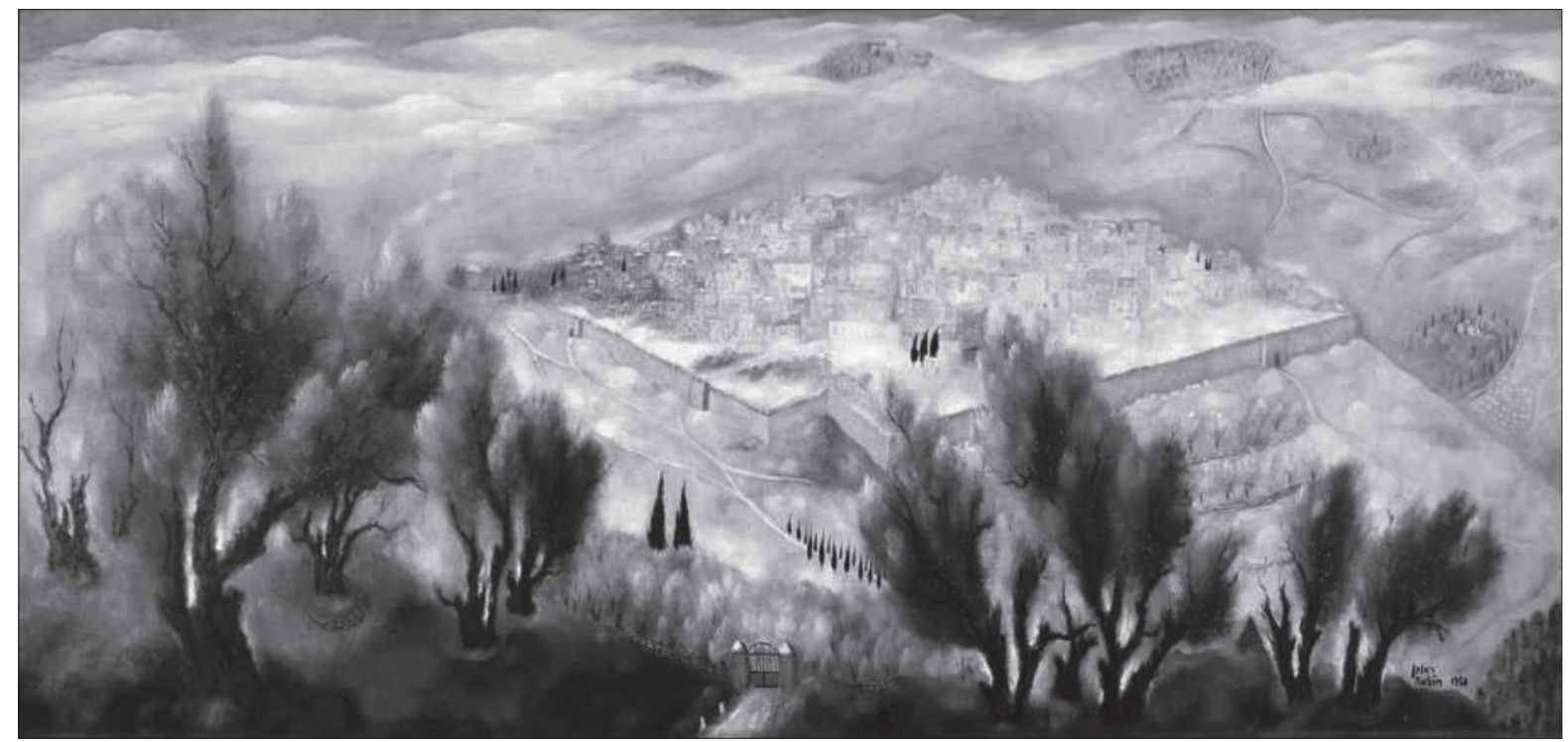

Fig. 4. Reuven Rubin, Heavenly Jerusalem (1958), oil on canvas, $250 \times 400 \mathrm{~cm}$, The Wolfson Museum of Jewish Art, Jerusalem

Earthly and heavenly Jerusalem is a multi-faceted city, realistic, mystical, transcendental and sacred to the three monotheistic religions. Since the destruction of the Temple and the exile of the Jewish nation, Jerusalem has been transformed from a realistic site to one that is mainly symbolic, a dream and an object of yearning for all Jews. Jerusalem's essential nature as a city of peace and ethereal vision reflects the meeting of matter and spirit, of the material and the sublime, of the earthly and the divine.

The works of Reuven Rubin (1893-1974), mainly those from the 1920 s and 1930s, offer a beautiful documentation of the natural and human landscape and of the life of the residents and their customs. His innocent visual language expresses a clear message of intense attachment to the country. Artist Yair Garbuz offers this description: "The course of his life was imbibed with Zionist ardor, and this fervor radiates from within. His canvases are the convergence of reality and imagination and the fusion of place and dream. When you mention Reuven, you speak of love of the land, pioneer romanticism, Jewish mysticism, and burning faith....'[16] Reuven himself stated that the country's landscapes were his motivating force and credo as an artist: "I see myself connected through my work to the people living in Israel, to Jewish history and to Jewish life in Israel".[17]

In his memoirs, he recounts that when he first arrived in Israel, he felt as if he had "arrived home" and the sites were all familiar from the biblical stories that he had heard as a child from his father. "For him, the Bible held the memory of Israel as the homeland, and conferred a sense of reality to his feelings of belonging to the place that was both

[16] Y. Garboz, [in:] Reuven Rubin - A Place, A Dream, ed. C. Rubin, Tel Aviv 2006.
[17] S. Brightberg, The National Painter, "Dapei Massa, Davar" daily newspaper, 1973, May 4. 
new and old".[18] In his works, he preferred to ignore the difficult reality of his times, and instead presented one that was wished for. Gideon Ofrat offers this summary: "His landscapes create a sense of openness and spaciousness of a magical country in which there are places to go and places to reach. There is a horizon and a path. It is as if he sought to conquer the land and integrate into it, on the canvas".[19]

In the 1920 and 1930s, Rubin frequently involved himself with the topic of Jerusalem. In his autobiography Reuven: An Autobiography and Selected Pictures (1984), he "testified" that throughout his life, he was captivated by the magic of the city. In the late 1950s, when he painted it again, the precise details and tight compositions faded almost completely and were replaced by free, Impressionist-like brushstrokes. However, in contrast to the Impressionists, who sought to capture, with the assistance of the light, the fleeting moment, Reuven achieved the same result, but for a different reason: He sought to dissolve the material, earthly scene and transform it into a heavenly one. His works became increasingly poetic and their atmosphere became mystical and spiritual.

After a long artistic success, as the land and its landscapes "conquered" his canvases and were immortalized by him, this artist of the soul of Israel reinvented himself in the 1960s. He assumed a new approach to the environs of Jerusalem, populated with the starring olive and cypress trees. His works from this period rely on a mimetic observation of the olive tree, which, in his paintings, became one of the symbols of Jerusalem. The thick, gnarled trunk of the ancient yet blossoming tree is strongly planted in the ground as a testimony of its natural ties to the earth and soil and to the age-old city of Jerusalem.

In his works, when the sun's rays meet the olive's unique hue of green, the leaves assume a soft glow that is elevated to a silvery-gray tree-top endowing the realistic scene with a dream-like quality that reflects the city's spirituality and sanctity. There, the clear, strong, ethereal and mystical shining light glints and shimmers.

The work Heavenly Jerusalem (1958) is drawn from a perspective that extends outward to all sides, and it focuses on specific elements that Reuven chose to emphasize. The very light colors of the city and its environs create a reverie-like atmosphere. The overall orientation is a view from the south-east. In the forefront are olive trees, and in the center is a path leading to a closed gate and to the Kidron River. On the right is the tip of the cone representing Yad Avshalom a first-century memorial tomb. In the center, Jerusalem is placed on a mountain, surrounded by a wall and mountains, some of which are inhabited. In front of the city is a combined view of the Temple Mount and the south-eastern corner. The edge of the octagonal Dome of the Rock is seen among the olive trees, with a wall of arches and three cypress trees to the south, and the $\mathrm{Al}$ Aqsa Mosque on the left edge 
(to the south). In the south-western corner of the city, Mt. Zion and David's Tomb are located. Along the southern wall, one can observe the Dung Gate and Zion Gate, and along the eastern wall is the Lion's Gate on the right with tombs along the wall and in the Kidron Valley. Behind the Temple Mount, which is in the center, is a kind of open space, probably for prayer, near the Western Wall highlighted in colors. Behind is the Church of the Holy Sepulchre and the square tower of the Church of the Redeemer. Inside the wall are the crowded houses of the city, some of which are domed. Additional churches, bell towers and minarets are evident among them. On the mountain slope, the road leads down from the Dung Gate to the Mount of Olives, flanked by a row of cypress trees.

Since Heavenly Jerusalem was painted during the years of Jordanian rule over Jerusalem between 1948 and 1967, it was based on memory and photos. Rubin's inaccessible Jerusalem, therefore, leaves the beholder remote and cut off from it, due to the different hues the artist used in the foreground and in the back, as well as to the paths that come to an end and to the wall surrounding the city. The mystical fog over the city enhances the feeling of separation and longing.

In this painting, Rubin documents Jerusalem as an observer from afar, from a wide panoramic angle and from a reverential position rather than that of intimacy. This is a well-composed painting of landscape and architecture. The artist depicts in detail every stone, tree, wall and hill. This particular, naïve approach provided him with a sense of embeddedness in reality and in the landscape. The paths leading to the holy city rise, and the view of the wall "reveals" a secret concealed. "Jerusalem's mountainous enclosure largely dictates that it remain in one's consciousness as an unattainable desirous goal'. [20]

The painting uncovers Jerusalem's treasures. With the sensitivity of both an artist and an investigative traveler, the artist immortalizes the city, bathed in light pastel colors. The old architectural city is set within the wall surrounding it while the buildings are akin to jewels set in a ring. The white fog around strongly emphasizes them, as does the slope facing the viewer and lying between the wall and a patch of dark earth in the foreground. Behind are sections of vegetation or inhabitation in the Jerusalem Mountains that are tinted in lyrical purples, pinks, yellows, greens and blues that add to their magnificence and splendor.

The soft white clouds above the mountain peaks, symbolizing purity, are suffused with sanctity, while transforming reality into a poetic map framed by the dark ground in the front with its olive trees. Their silvery tops offer a light, feather-like quality, turning into a glowing halo and a flowing illumination. This is another dimension of light and spirituality.

"Initially, I had the sense of being a Jew, but not merely a Jew from Poland, from my village. Here, there was something I was not

[20] Ibidem, p. 35. 
familiar with although I had read about it in the Bible. In my youth, I prayed and remembered Israel".[21]

Max Bronstein was born in 1896 in Tuchów, Poland and in 1933 emigrated to Jerusalem, where he changed his name in 1936 to Mordecai Ardon.[22] One year after his arrival in Israel, Modecai Ardon (1896-1992) painted in an expressive style that diverged from the popular realistic-romantic approach at the time, to which the artists in Israel were tethered. He stated that: "In the new reality, past, present and future are included, and the artist attempts to express the surrealist and metaphysical aspects of the events as they occur... today the artist wishes to give a spatial dimension to the interactions of all three, as they were fused together in the new reality".[23] The sense of fate and the mystical approach to reality transfer the artist back to the treasures of the past, but this time, not to the reservoirs of folk-

lore, but to the antiquity of the historical development of the Jewish people thousands of years ago, and to the mysteries of the Kabbalah. Ardon emphasized the presence of a mystical atmosphere in the Land of Israel and professed his belief that an artist should have almost physical contact with the target object, in order to be able to exhibit its metaphysical properties.

In his works, we meet a mix of German expressionism, cubism, and the spirit of Israel. "The Jewish town and tradition have become metaphysical in his work, and that spirit bordered on the novel 'Canaanite' approach, which was more symbolic and abstract than that of the other so-called German artists in the country".[24] As a student of the theoretician and abstract artist Vasily Kandinsky, from whom he learned of the novelty of mystic emotionalism, and of Paul Klee, who argued that "Art does not convey the visible; it creates it",[25] Ardon developed a visionary metaphysical style. In addition, he was also inspired by rabbinical literature and legends, by Jewish religious and Kabbalistic symbols, and by Jewish and individual mysteries. In the home of his father, the watchmaker, he learned about the mysticism of time, which plays a key role in his works. These are meticulously planned, carefully

[21] K. Katz, Interview with Modechai Ardon, "Ariel" 1963.

[22] B. Roth, The Jewish Art, Tel Aviv 1956, p. 800.

[23] A. Schwarz, Mordechai Ardon: The Colors of

Time, Tel Aviv 2003, p. 19.
[24] B. Tamuz, O. Levita, G. Ofrat, The Story of Israeli Art: From Bezalel in 1906 to the Present, Tel Aviv 1980, p. 107.

[25] J. Sallis, Klee’s Mirror, New York 2015, p. 35.
Fig. 5. Mordecai Ardon, Tamuz (1962), oil on canvas, $158 \times 127 \mathrm{~cm}$, private collection 
executed, and touched by the almost-abstract, following his training in the precise, structural Bauhaus style that restrained the emotional, German expressionism.

The artist was, naturally, drawn to the light, which he turned into an important means of expression, and sought to express it "not only externally - impressionistically - but also to conquer it from the inside and to express, by means of it, the primordial reverence evoking nature of the land".[26]

In the context of his approach to the landscape, the skies and the celestial bodies turned into a central motif in his prolific body of work; for this reason, Ardon won the title "the artist of the stars". We can draw a direct line from him to Vincent van Gogh, who, in his loneliness stated: "When I am in a terrible need of religion, I step outside and paint the stars". [27] Van Gogh's final work was Starry Night (1889).

The colorful variety of the stars, their sizes and glow and the enormity of the stellar distances, ignite people's imagination - especially Ardon's, whose skies are at once material and spiritual. Popular beliefs, including superstitions and involvement with the horoscope - all add to the heavenly mysteries. Gideon Ofrat adds "Mordechai Ardon never stopped reaching for the sky for in his paintings it is the ultimate 'place'. It is the ethereality that gives his work its Jewish metaphysical spirituality and greatness, and that same ethereality supports, too, the symbolic abstraction, (not to say 'surreal') of his language. But more than anything, the nearly permanent celestial place in the artist's work attests to an open, unhealed wound that he had carried in his heart since the mid1940s, caused by the shock of the Holocaust". [28] As a result, Ardon sometimes describes cosmic chaos or what appears so to man, who lacks the tools to understand the inherent logic of Creation. "Thus, the artist attempts to criticize the absence of Divine Providence that fails to establish order in a chaotic universe".[29]

As in other works of modern art, the painting Tamuz - the eighth month in the Jewish calendar - (1962) disrupts the viewer's expectations. The title of this work hints at a burning orange color that would describe the scorching summer month of Tamuz in Israel. However, the work is dominated by cool, velvety blues that illuminate it, accompanied by a pink moon and an abundance of pinkish, greenish, purplish and whitish circles. "In this work, Ardon revealed his yearning for the skies stretching over Jerusalem in the month of Tamuz".[30] Alongside these, a large, dark image - a female or a musical string instrument, with two F-holes marking the neck and the location of the abdomen and the uterus - can be discerned.

[26] Z. Amishai Maisels, Past and Present Came Together - Ardon's Work, Catalog of Ardon's 1985 exhibition, Tel Aviv: Tel Aviv Museum of Art, 1985. [27] <https://www.brainyquote.com/quotes/vincent_ van_gogh_106038>.
[28] Gideon Ofrat, "In Morcechai Ardon’s Skies", "Machsan".

[29] D. Giladi, Tracks in Art 82 Painters in Israel, Tel Aviv 1989, p. 27.

[30] Ibidem, p. 28. 
The night scene is mystery-laden, bedecked with suppressed sexuality. The round provocative form clearly symbolizes wholeness - the very metaphysical, spiritual completeness the artist is striving to attain. We keep discovering illuminated and darkened cosmic bodies in his skies, such that are adorned with clouds sprinkling disorder through their amorphous shapes, and fragmented forms that may represent human prayer reaching upwards. Furthermore, the heavens are embedded with symbols and signs influenced by reality and by overt and covert Kabbalah symbols. It was his attraction to Kabbalah that imprinted his work with Jewish spirituality. Ardon's skies have frequently been associated with innumerable ladders aimed upward to the Jerusalem skies. The ladders will join earth and sky by creating a bi-directional track. Though it will forever remain without angels or humans, it will represent man's potential to communicate with God and vice versa.

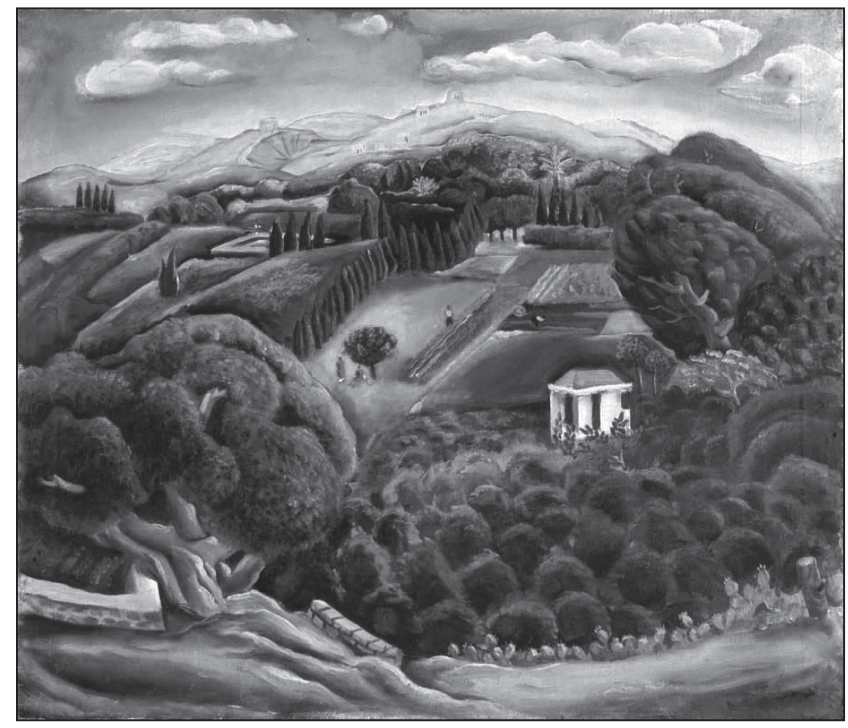

"The sun, moon and stars that float in Ardon's nocturnal spaces are there as 'time versus place' and 'place versus time' - time that is hanging in the artist's world, like those childhood clocks hanging in his consciousness; like the time of the Jewish holidays, recited as: 'in those days, and at this time"'.[31] His clocks show all the hours simultaneously, as infinity with no beginning or end.

By the end of the $19^{\text {th }}$ century, some parts of the Sharon Plain, which lies between the Mediterranean Sea to the west and the Samarian Hills, $15 \mathrm{~km}$ to the east, were very fertile, but much of it was swampy and malarial, a condition exacerbated by massive Ottoman deforestation. The first Zionist settlers drained much of the swampy land, and populated the region with many settlements. In 2008, it was the most densely-populated region of Israel.

Nachum Guttman (1898-1980), a pioneer of Israeli art in the 1920 , frequently depicted the new reality that developed in those years in the Land of Israel in a naive and idealistic style. Author Adam Baruch argues that in Guttman's works, "dream and idyll are part of the artist's factual reality".[32]

Guttman's paintings, similar to his literary works, tell the story of the place where he grew up, and reflect the historic transformations that occurred in the country from his childhood until his death. His art grew out of his innocent, naive worldview, corresponding to that of the settlers. Most of his works are not an accurate representation

Fig. 6. Nachum Guttman, Landscape in the Plains (1920), oil on canvas, $67 \times 78 \mathrm{~cm}$, Nachum Guttman Museum, Tel-Aviv 
of the reality of the time, but rather a re-production of expectations, hopes, dreams, and desires.

The artist stated, "I am not an intellectual cognitive painter, but rather an emotional one... In my paintings I try to induce wonder, which is the key to primal, fresh vision, and the wonderful element in life that must be expressed in art"; [33] adding, "I was enthralled by the views that satiated my eyes".[34] His works indeed evoke a strong sense of powerful connection to the land, as a native child rather than as A Guest For the Night, [35] and being Israeli made him strive towards the Jewish sources, the Bible and the image of the early Hebrew man. Alongside this orientation, Guttman is also influenced by a romantic perspective that views the local authentic Arab as one who preserves the ancient biblical way of life. He, who was wholeheartedly a Zionist, by emulating his friends in the Canaanite Movement[36] sought to escape the figure and image of the pale, weak Diasporic Jew, as well as avoid any discourse concerning the Jewish shtetl and the Diaspora.

Author Ehud Ben Ezer astutely expressed the essence of Nachum Guttman, stating that as time passes and authors and readers feel an increasing need to latch onto the origins of the landscape of the legendary Land of Israel, to the mythology of the birth of the nation, to the rising of a city from the sands, to the intensifying search for an ancient root of identity, "so will Nachum Guttman's role as author and artist be recognized, since his paintings and writings were such an essential part of the collective memory of the renewed Hebrew culture in the Land of Israel".[37]

Landscape in the Plains (1920) is one of Israel's most refreshing and authentic landscape paintings. Using a variety of rich greens, close to the browns ranging from light yellow to orange, the artist conveys the view's vitality - an abundance of vegetation, grass, bushes, and a variety of trees. Alongside the sense of naturalism and openness, the fingerprints of the farmer are evident. Except for the sky and three groups of clouds floating above in addition to the round hills, everything that occurs between them and the foreground, where the viewer is situated enjoying the vistas, is man-made. In the foreground, side-by-side and one after the other, are citrus trees that evoke the scents of orchards that are so typical of the Land of Israel and the Sharon Valley. Left of the orchard, for balance, a thick olive tree fills a considerable space: alone

[33] N. Gutkind, Nachum Guttman: The Enchanted Realist, "Hatsofeh" 1969, June 20.

[34] E. Ben Ezer, Between the Sand and the Blue Skies, Tel Aviv 1980, p. 140.

[35] S. Agnon, A Guest for the Night, Tel Aviv 1938. [36] In 1943, poet Yonatan Ratosh (1908-1981) published "An Epistle to Hebrew Youth", the proclamation, the manifesto, the first written communication of the Canaanites, a literary and artistic movement that had been active for some time. In this essay,
Ratosh called on Hebrew speaking youth to become a buffer against Judaism. He declared that between the youth that had settled in the Land of Israel and the Jews of the Diaspora there was no true connection. This became the characteristic cry of the Canaanites, whose members proposed a return to the mythological past, in order to create a Hebrew-speaking nation with an independent identity.

[37] E. Ben Ezer, Lectures in Tel Aviv, Beit Hakibbutz Haartsi 1992, March 24. 
and expressive, manifesting the antiquity of the land, its gnarled trunk and branches express the embeddedness in and hold on the land, along with its inner force. Behind the orchard is a lone building, distinctive in its white color and orange roof, as is the colorful patch of land in the center. At a distance, fertile cultivated plots are depicted, testimony to man seeking to revive and live off his land. Among the rows of cypresses, planted singly or in groups at the foot of the hills and the other vegetation, symbolizing order and demarcation, evoking a somber air and a sense of firmness and permanence, palm trees poke out. These, like the olive trees, are symbols of the ancient past and of the Mediterranean, conveying an exotic presence. The trees carry their tops high, gazing beyond territory and time.

In the foreground, to the right of that expressive olive tree, is a row of cacti, in yet another hue of green, different from the orchards' green. The origin of the cac-

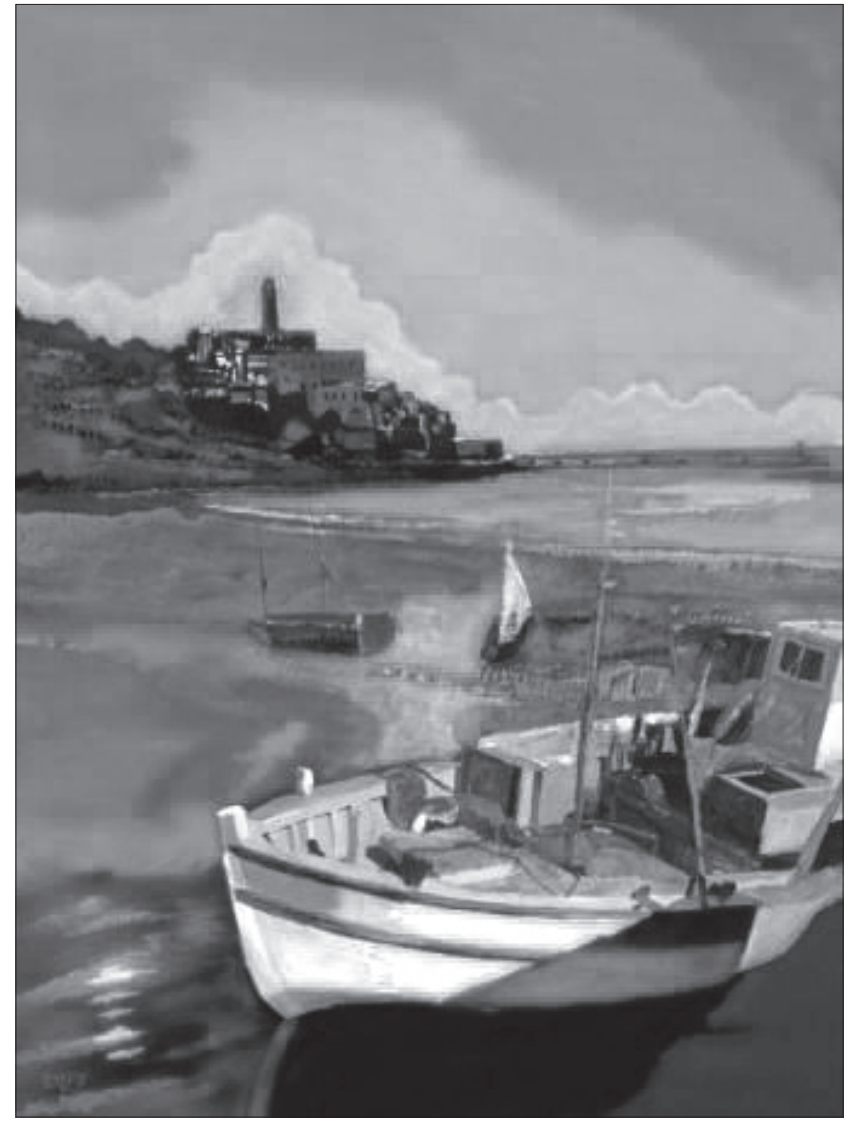
tus is South America. It took root in Israel and spread and became its emblem, symbolizing the native-born "Sabras", prickly on the outside but soft and sweet on the inside.

The sea is one of the symbols of Tel Aviv. The Mediterranean, the western border of the country and the city, adds wide-open spaces, light, mystery, color and vitality, and together with Jaffa, it receives expression in Oded Feingersh's work The Fishermen's Boat in Jaffa (2013). According to Gideon Ofrat: "Israeli painting in its inception 'had its back to the sea'... but when the sea filtered into the arts it did so in an enormous, provocative, colorful, visceral burst". [38]

Oded Feingersh was born in Jerusalem in 1939 and graduated from the Bezalel Art Academy. Oded studied art in Paris, Brussels and Madrid. Feingersh's work is influenced by worldwide styles, including social realism, naturalism, pop-art and surrealism. Following a magnificent career in his unique surrealist style, in 2000 Feingersh turned to painting Israeli landscapes. His sensitive paintings center around typical sceneries, in the style of artists exhibiting during the 1920 s and 1930s: bold colors, visual wealth, a profusion of light and largely impressionist-style brushstrokes. His acquaintance with the country's mountains, valleys, rivers, trees, and flowers has always been deep and

[38] Gideon Ofrat, at the opening of Oded Feingersh's exhibition "The Same Sea - Shores", June 7, 2012. "E-Mago, Magazine for Articles on Culture".
Fig. 7. Oded Feingersh, The Fishermen's Boat in Jaffa (2013), oil on canvas, $90 \times 120 \mathrm{~cm}$, private collection 
intimate. Sometimes, he depicts spots of beauty and other times, extensive panoramas that fill huge canvases, all of which speak to a bond of love, of ownership, and of commitment to the land. As Feingersh stated, "Converting the Israeli landscape to the medium of painting is a substitute for graffiti that constitutes a declaration of its territory our territory".[39] Although his birthplace was Jerusalem, which he frequently paints, he currently works in Tel Aviv and portrays the many aspects of this vital, thriving, secular city.

Connecting the world of the here and now with distant times and places, real and imaginary alike, Oded Feingersh (1938) possesses a wild imagination free of frontiers or constraints, generating sights and states that seem real, but are essentially a fantasy - pink, gold or black. He demonstrates a prolific output of a multi-disciplinary artist whose fertile and convention-breaking mind has, for the past five decades, yielded paintings, drawings, sculptures, illustrations, poetry and prose. The artist sometimes documents the constantly changing dynamic existence, while at other times, his colorful imaginary universe or hallucinatory environment consists of images nearly reflecting our realistic world.

In Feingersh's work, the image of one of oldest ports in the world, mentioned in several biblical books, situated on a high rock, is immediately identified by its peninsular shape that juts out to the sea. Jaffa's contribution to its sister, Tel Aviv, is its thousands of years of history as an ancient port city, compared with the latter's one hundred years' existence. Jaffa offers a mythological space whose roots are traced to the city's founder, Yefet, the son of Noah. It was the town in the district of the tribe of Dan, the site where Jonah ran away from God and boarded a ship to Tarshish (Jonah 1:3). It was here that Hiram the King of Tzor sent Cedars of Lebanon on rafts for the construction of the First Temple (Chronicles II 2:16).

This is the same Jaffa appearing in Oded Feingersh's work, but even though the image is dominated by the closeness to realism, the imaginary dream-like qualities are enhanced as well, due to the magnificent, bold, unrealistic colors, as the hues of turquoise are typical of the Caribbean Sea but not of the Mediterranean. The colors glow in blue, purple, yellow, and green, diluted into each other, creating a mirror-like surface reflecting the picturesque fishing boats anchored in the bay. The angle of vision focuses on the rounded bay, beneath the rocky cliff of ancient architectural features, protruding from the sea. The tower of St. Peter's Church is prominent in the distance. White clouds hug the horizon, while three golden clouds are floating in the sunset-colored sky, hanging above the light that shimmers on the water surface. Despite the fauvist, European palette, a naïve palette bursts through. On Feingresh's shore, the scent of the Orient and the Mediterranean, lingers on.

[39] O. Feingersh, To Lick Fire, Retrospective Exhi-

bition: 1964-2014, Catalog, Ra'anana: The Municipal

Gallery in Beit Yad Lebanim, September 2014. 
Mt. Tabor is a prominent peak that protrudes south of the Nazareth mountain range and north of the Yizre'el Valley, and is one of the highest in the Lower Galilee, as it is visible from the fertile Galilee and the Golan Heights.

The mountain is shaped almost like a half-sphere, suddenly rising from rather flat surroundings and reaching a height of 575 meters, thus dominating, by a good 450 meters, the next town in the plain below.

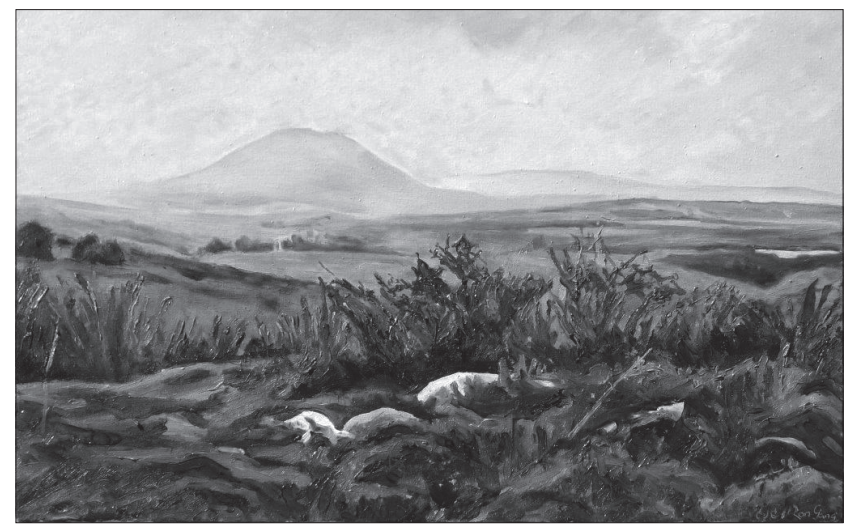
The Catholic Church at the top is quite visible from afar. The mountain is isolated and rising abruptly from gently sloping or level surrounding land and is not volcanic.

Ron Gang (b. 1950) is one of those artists who exit the studio Fig. 8. Ron Gang, Mt. Tabor (2014), $41.64 \times 66.04 \mathrm{~cm}$, Artist's collection and "plant" their easel in the field in all seasons, opposite the view, as they become immersed in nature, blending with it. He frequently depicts the Negev desert, which is close to his home, while he wonders whether the veracity of color and form can exist simultaneously. His love for the country and the land, his commitment and his deep ties to them, pervade every region drawn by him. Sometimes the landscapes appear to have originated from the Bible, due to their dramatic bold colors, though their topic seems pastoral.[40]

Gang came to Israel from Canada as a young man, motivated by a Zionist passion that has not faded over the years. "Despite his young age, he belongs to the generation of pristine innocence of Ludwig Blum, with his deserts, dry riverbeds, stratified hills, and infinite plains".[41] Gang remarks that he continues to work the land, not through traditional agriculture, but through his paintings. He argues that being so strongly tied to it is what makes him a realizer of Zionism, since the land belongs to whoever tills it: "A person who does not till the earth, breathes its smell or gets his fingers dirty - cannot truly paint it".[42]

He tends to sit quietly, situated in a spot that stimulates the eye and the heart to immerse in it, an action that corresponds to meditation prompting heightened awareness. In his mode of work - direct observation of nature - a painting is just a side-effect accompanying the process: "When I am in the field, what is seen on the canvas appears to be a reduced reflection of everything that I feel and experience, but when I look at the painting again in the studio, this time the canvas does convey the vitality of the larger experience".[43]

Landscape paintings are not overly popular in the post-modern era, as art is frequently involved in social and political issues. Ron Gang, however, elected to disregard these issues, and the reality present in his

[40] U. Tsur, Shuts One Eye - An Innocent Exhibition: From the Innocent Look to the Innocence in Death, "Kol Hanegev", "Ha’aretz" 2002, April 26, p. 37. [41] Ibidem.
[42] R. Gang, Across Nature - Silence and Infinity, Ground for Action, "Tarbut" 2002, April 26.

[43] Idem, The Communication Channel 2010, April. 
paintings is devoid of any connection to the communications media or to current events. Ziva Yalin, curator of one of Gang's exhibitions entitled "The Art of Nature: A Universal Topic",[44] stated that the reality in his paintings is spiritual, quiet, introverted, harmonious and mystical; a reality in which time is eternal, in which all contrasts are balanced out and disappear. Ron Gang considers his art as being in a state of consciousness which mystics call "the eternal now", when the viewer experiences the moment as an eternal totality extending beyond time. He confesses, "The landscape painted itself; I did not. It was not me. I was only the instrument, just the conduit through which everything recorded its presence".[45] In another exhibition, "Delving In", he stated that there is so much more than meets the eye at first glance and therefore, the deeper one immerses oneself, the more treasures are to be discovered: "I have been painting the same landscapes for decades but still, the same place seems to be different every time, as if I had not really seen it the previous time; as if it isn't the same place at all. The season changed... and every day differs from the last and the next. Changes occur regarding the light and the atmosphere, and even the viewer is not the same as he was yesterday".[46]

In the work Mt. Tabor (2014), an exciting, impressive sight extends from the foot of the mountain. With exceptional sensitivity, reflected in infinite shades of green, Gang, a distinctly plein air painter, conveys the fertility and freshness of the Yizreel Valley that stretches at the foot of the mountain. The artist's opulent usage of shades of green is the skill of a local native, firmly connected to the soil and its vegetation. The range of greens recalls the mastery of the romantic English painter, John Constable, who immortalized the infinite greens of his homeland.

The unrestrained strokes of his precise, fertile brush, influenced by the impressionists, approach the abstract and create a landscape that is a mixture of poetry and realism. This is how he "describes" rocks, bushes, hills, plots of land and the fog, hanging over the mountain, wrapping the sky as a lace scarf. The skies are bestowed with sensitive, poetic shades of light blue, pink, white, yellow and lavender; these are especially prominent on the mountain's rounded peak. He transforms Mt. Tabor into an idyll of quiet, of beauty and aspirations toward spirituality, not unlike Paul Cezanne's famous Mont Sainte-Victoire series. A sense of wide expanses and open, borderless spaces "overtakes" the landscape while bursting through the painting on both sides.

The Jordan River originates approximately 200 meters above sea level on the slopes of Mt. Hermon. It ends its course at the lowest spot in the world, the Dead Sea. Along its course, the Jordan feeds the Sea of Galilee. In its course from the Sea of Galilee to the Dead Sea, the Jordan travels a winding 230 kilometers. Being one of the most famous rivers in history, in literature and in theology, the river played

[44] Z. Yellin, The Art of Nature: A Universal Subject, "Wildlife Art Magazine" 2005, January-February, p. 20-21.
[45] R. Gang, “Communication Channel 2010, April.

[46] Idem, "Heetamkut” 2013, March 15. 
a strategic role in the Bible as well, where it is mentioned 175 times in the Old Testament. The Book of Joshua mentions, for example, how the Israelites crossed it upon entering the Land of Canaan. The Book of Judges recounts how the tribe of Ephraim blocked the crossing places to cut off the escape routes of the Midianites retreating so as to escape Gideon. It is significant for Christians because John the Baptist baptized Jesus in the waters of the Jordan and Christian pilgrims come, therefore, to immerse themselves in its holy waters as

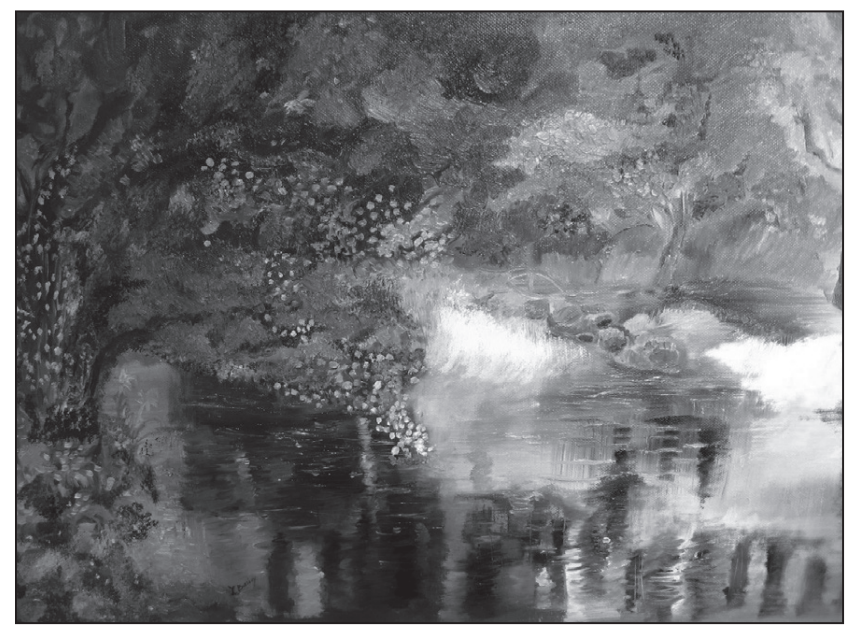
part of a religious ritual.

Larisa Bersky (1967-2015) immigrated to Israel from the former Soviet Union in 1993. In her case, her talent and passion for nature-paintings enveloped by fantasy, eased the harsh realities of the disintegration of her original society and the absorption difficulties Fig. 9. Larisa Bersky, The Jordan River (2012), water color, $80 \times 100 \mathrm{~cm}$, private collection in her new country.

The Jordan River (2012) features the flow of the river with numerous rocks, waterfalls and thick vegetation, thickets of reeds and weeping willow trees that create "forests" on the riverbanks. In addition to the willow, there are typical riverbank plants, such as ash trees, with their tooth-edged leaves; oleander, whose large pink flowers bloom in the summer; and holy bramble, whose sweet flavorful fruit ripens in the summer. At some distance from the water, Christ's thorn grows. Many birds hide in the thick growth on the riverbanks, such as herons and moor hens, and fish populate the river. The painting evokes associations with the poem The Choir of Small Voices by French poet Paul Verlain. Similarly to that poem describing the supposedly insignificant small sights and voices of nature,[47] the viewer in Bersky's work "hears" the whispers of the forest, listens to the whistling of the wind, and to the rustling of the leaves or to the delicate twittering of birds, the swishing of a lizard passing by, the hissing of a snake, the sounds of pebbles tumbling down a river, and the ripples of the stream. The poem conveys the impressions similar to those by impressionist paintings. Artists like Claude Monet, Camille Pissarro and others, addressed the fleeting moment, the changing light and the supposedly incidental and marginal sights in nature.

In Bersky's light-filled painting, a colorful, scented fragrance rises from the waters of the Jordan River that flow quietly at the foot of plants growing on its banks, in an atmosphere recalling children's

[47] Ruth Karton-Blum and Anat Wiseman (eds) Meetings with a Poetess, Tel Aviv and Jerusalem: Sifriat Poalim and the Hebrew University, 2000. "Leah Goldberg understood that huge things exist in order to enable small things to exist, and that true culture exists not in the storm and the loud noise but in the silence of a person's soul and his feelings. The voice of culture is in the human's voice speaking song and its language is the living language". 


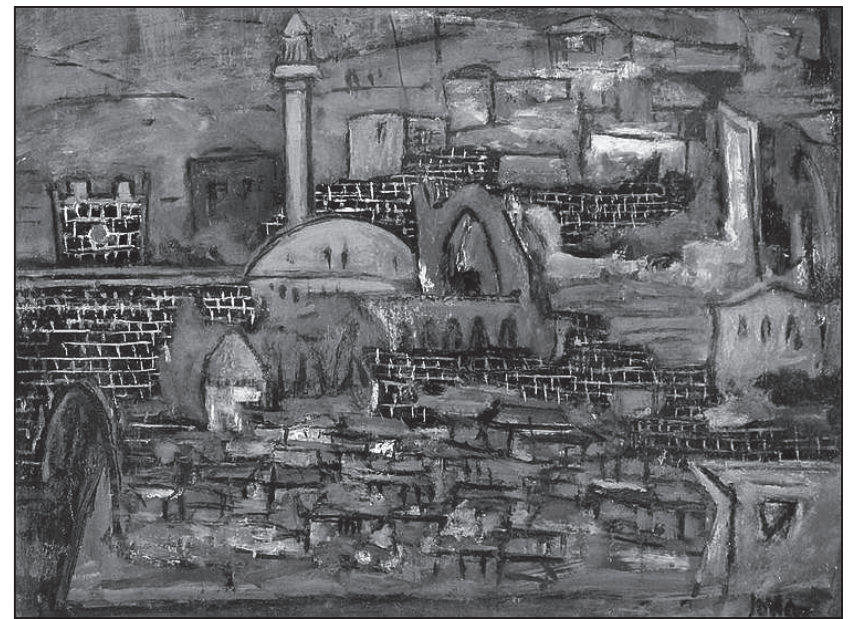

fairytales and fantasy. Through a wealth of blues and purples, the flowing water in which the almost-impressionist light is reflected, the minute vibrations of the calm, slow flow, is easily felt. Replacing the sky is the thick vegetation, sensitively depicted through the colors and the smallest movements of the leaves and flowers. "Using soft pastel shades, in aquarelles, Bersky softened the bold colors of reality, and reality was transformed into the wondrous sights in her paintings; paintings of a poet”. [48]

Tiberias is located on the western

Fig.10. Marcel Janco, The Market at Tiberias (1944), coloured lithograph, $77 \times 100 \mathrm{~cm}$, The Magnes Collection of Jewish Art and Life, UC Berkeley shore of the Sea of Galilee. Established around $20 \mathrm{CE}$, it was named in honour of the second emperor of the Roman Empire, Tiberius. Tiberias has been considered one of Judaism's Four Holy Cities, along with Jerusalem, Hebron and Safed. In the 2nd-1oth centuries, Tiberias was the largest Jewish city in the Galilee and the political and religious hub of the Jews of Israel.

Having achieved an international success as one of the leaders of the Dada Movement, Marcel Janco (1895-1984) reached the Land of Israel "absorbing the glamor of the sun-drenched landscapes, the proliferation of vegetation, serene villages and open spaces of its desert plains. A new experience overwhelms him with warmth, creating the basis for an internal rejuvenation". [49] Immediately after arriving in Israel, Janco begins to paint the country's scenery, its people, and its sights. The art critic Haim Gamzu described the style of the artist: “...his quick brush transformed the buds of the abstract into a forest of tangible experiences. Although his world is not the world of realism... a disoriented trance pulses through each composition... but the distance between these two worlds is not great. Occasionally they coincide...."[50] According to art critic and theoretician Eugene Kolb, "Janco searched for the everyday magic and for the melody of his soul".[51]

In his early years in Israel, Janco accommodates his new audience by painting figurative and even realistic works, although he never "betrayed" his true self, and remained faithful to his unique style, in which the topic became an "excuse" for mixing shapes and colors to create a unique aesthetic harmony.

Despite the changes in his style and in his environment, several typical lines run through his work: the strong ties to life, an architectural perspective of art, a sense of humor that frequently dominates his works including the social-human element, French-intellectual deviousness,
[48] Tatania Klimovitch, "Haifa Weekly", August 13, 2016; <http://klim-reporter.com/20154.html>. [49] M.L. Mendelson, Marcel Janco, trans.

V. Schwartz, Tel Aviv 1963, p. 12.
[50] A. Yaffeh, Marcel Janco, Tel Aviv 1982, p. 73.

[51] Ibidem, p. 74. 
the presence of the grotesque and the absurd during the crisis of war, a soft smile of compromise in his latest works.

Using a dominant, black, expressive line characteristic of his work, Marcel Janco defines and maps The Market at Tiberias (1944), a city both colorful and peaceful, stretching over the hills, crouched under the cliffs adjacent to the Sea of Galilee. The background in the left alludes to the Golan Mountains, at whose base the city is located. The Sea of Galilee receives some attention in the background on the righthand side, and close to the viewer. Although its presence is far from being dominant, it signifies the blue of purity and serenity. A sense of oriental mystery and beauty arises from among the architectural forms reminiscent of arches, domes, mosque-like buildings, and minarets. All is pervaded by the scent of ancient Tiberias, rising through the whiteblack bricks that surrounded the city and determined its boundaries until the early $20^{\text {th }}$ century. These walls, whose remains are evident today, were constructed by Daher el-Omar, ruler of Galilee, in the $18^{\text {th }}$ century, and have since been destroyed repeatedly by earthquakes, war, or change of rule. The walls, the buildings such as the fortress and the leaning tower, are visual symbols of Tiberias and appear in the city's official emblem.

Janco presents Tiberias' dense population through colorful geometric forms, which emphasize the architectural element inherent in his work - after all, he was an architect. "Each of his works is planned as a strong, stable steel skeleton frame. In more general terms, one can say that his art tends to merge architecture with the plastic arts in a single comprehensive 'structure'”' [52]

The magic of the Orient is reflected in the city's powerful, bold, poetic and colorful vibrancy, as stated by Haim Gamzu: "His was an excessively sudden and sharp discovery of the Orient, blinding with its spectacular colors, and he was swept by the unrestrained stylistics".[53] Janco creates a harmonious blending of intellectual and sensory elements and a mixture of the tangible and the abstract, as he accurately describes the character of the place with a merger that creates a structure of creative chords involving color and line. The heat in the depiction of Tiberias creates sensuality that originates in reality and is influenced by Dada. Gamzu concluded that "A painting by Janco is a joy to the eye and a challenge to the imagination due to its surprising, original colors and its suggestive forms".[54]

For thousands of years, the ancient city of Safed was conquered and reconquered, always changing hands. Since the 16th century, it has been considered one of Judaism's Four Holy Cities, along with Jerusalem, Hebron and Tiberias. Since that time, the city has remained a center of Kabbalah and Jewish mysticism. The old city streets and houses are steeped in Kabbalistic influence, with the doors and windows 


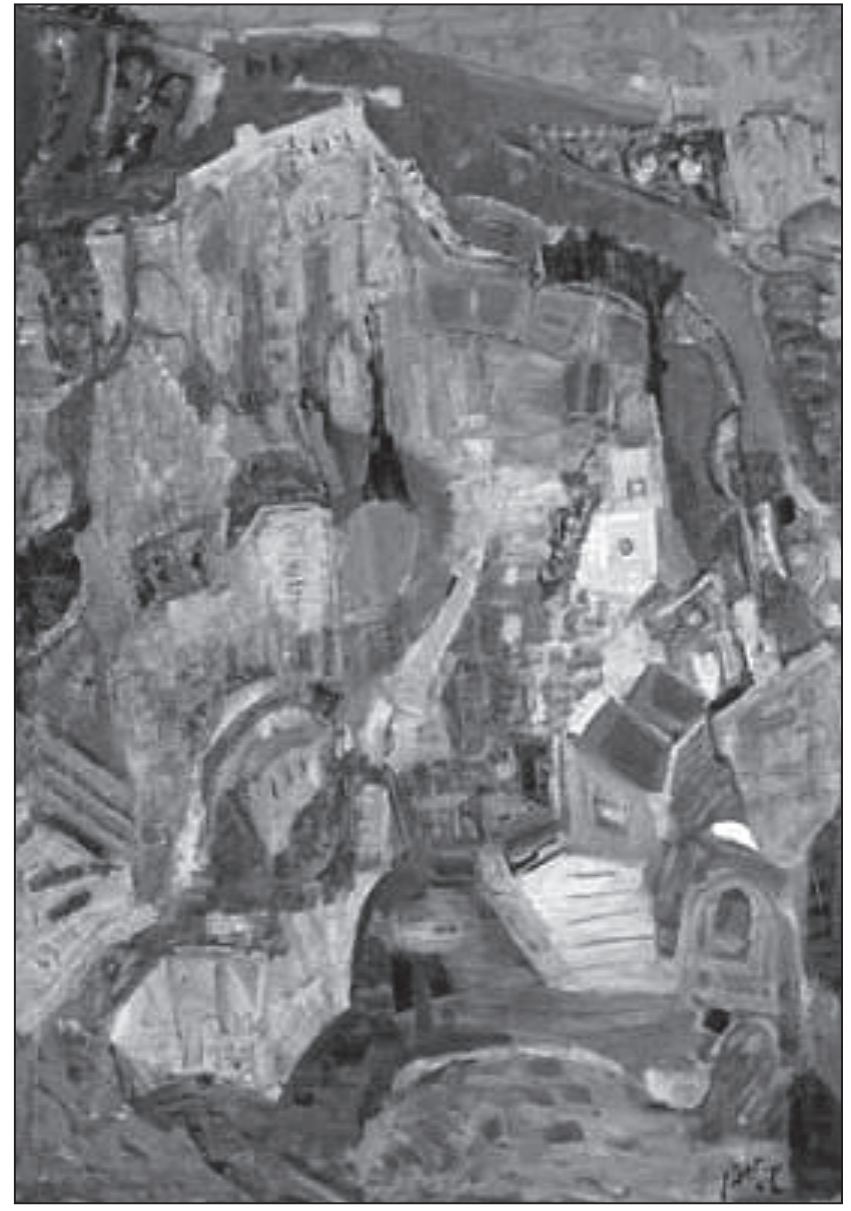

painted blue in mystical symbolism to confuse evil spirits. Safed is not only one of Israel's holiest cities, it is also the highest city in the Holy Land, set in the dense pine forests of the Upper Galilee, overlooking Tiberias and the Sea of Galilee.

Levanon is considered one of the founding fathers of Israeli art. Like most of the artists in his time, he was enchanted by Israel's illuminating light and its play of colors, which remained a remarkable sign of his oeuvre. As Giladi put it: "Like a sleepwalker bemused by the country's magic, Mordechai Levanon (1901-1968) wanders among us, detached from reality, gliding on the wings of enraptured imagination".[55]

In some works, Levanon's symbolism turns into abstraction when the landscape does not have distinct contours of topography. A Levanon edifice is unhampered by realistic restrictions floating freely on the lyricism of form and color: sloping rectangles, solid squares, rings or opaque circles, lined bands one above the other holding together the fantasy in the

Fig.11. Mordechai Levanon, Safed (1964), oil on canvas, $100 \times 72.5 \mathrm{~cm}$, private collection background. The boundless freedom of his paintings stands as an example of subtle abstraction with a tremulous delicacy about it. Levanon's magical work has a wonder and majesty, but its magnetic quality is derived from the basic truth therein. [56]

The artist's heart beat with the spirit and idealism of the new land and the pioneer spirit, as he was imbued with the aspiration to build that spiritual land based on its material foundation, into which, through his work, he breathed life. Author David Giladi explained the source of Levanon's longing for higher spheres: "It was in the artist's childhood village, in that house of prayer where the parochet [ornamental curtain] covered the holy ark. This parochet was always waving before his eyes and accompanied him everywhere he went". [57] His work was not intellectual but rather emotional, and he was blessed with "the wisdom of the heart and a fusion of intelligence, intuition, mystical magic, Hassidic fervor and songs of thanksgiving". [58] Lyrical, modern, original, and deeply rooted as were many of the artists of his period, Levanon was enchanted by the radiant light of Israel and its palette of
[55] D. Giladi, Mordechai Levanon, Artist and His Work, Jerusalem 1970, Introduction.

[56] Ibidem, p. 8.
[57] D. Giladi, Tracks in Art: 82 Painters in Israel... p. 128.

[58] Miriam Tal, [in:] D. Giladi, Mordechai Levanon..., Introduction. 
colors, which became a distinctive mark of his work. "He has in him these lofty hues... and spectra of shades and he combines them with each other in a blooming wondrous fusion". [59]

His paintings are based on existing landscapes that he reproduces rather freely on his canvas, as his impressions "relocate" them through his expressionist style. His houses and mountains seem to rise and float in the sky, infusing the painting with an ethereal element of joy, as he makes them round and square, raises and lowers them and through his "inner self", transforms them into a magic, lyrical dream replete with the magic of Creation. "His landscapes [...] are full of mysticism, like unreal ecstatic visions".[60]

Levanon does not transform nature into a symbol. His intention is to "embody the 'soul' of nature of an ancient holy city such as Safed into a vision of religious devotion, and that is the reason for its theatrical or decorative appearance. The deep religiosity that underpins his artistic perception seeks out a plastic form for the festive nature of his spiritual ardor". ${ }^{11}$ Poet Yeshurun Keshet referred to Levanon as to a "spiritual visionary" and added: "All his paintings are variants of a single inner painting of some 'city of God." [61] His landscapes, which appear ornamental mainly due to their spectacular colors, are not. In effect, they are super-natural. The main point, for Levanon, is not to be looked for inside the painting, as it is hovering outside it.

His paintings of Safed, as those of Jerusalem, are defined as "magical landscapes". He illustrates the holy city using the artistic means that are conventionally referred to as "expressionist symbolism"; he expresses his longing, as a European, for the mysteries of the Orient, and conveys a serenity that alludes to the secrets buried in the landscape and the rocks. The spiritual history of Safed is translated into colors and forms. In his style, saturated with religious fervor and spiritual exhilaration, he "documents" the city's vistas and buildings, which were influenced by Jewish mysticism, but are mainly populated with soil and stones, with very little sky, even though the artistic aspiration is to reach these skies and penetrate through them.

In a tall vertical composition, Safed (1964), the artist reflects the city's congestion, its narrow alleys and its secret poetic atmosphere that has descended upon it while enveloping it as a halo. The vegetation, the buildings, and the topography point and aspire upward. The texture of the growing plants is of flat colorful patches of more or less precise geometry, and a high degree of abstraction and oriental color enhanced as it is bathed in pinks, purples and greens, as the city rises as a curvaceous mound. The generally abstract appearance occasionally gives way to specific, distinct objects: a light spot of color recalls stairs, low houses with slanted roofs, and a path winding up the mountain. Dream-like, real, and imaginary Safed spreads toward the sky. It is

[59] Haim Hazaz, [in:] D. Giladi, Mordechai Levanon..., p. 16.
[60] G. Ofrat, Mordechai Levanon: The Mountain and the Palace, "Hamachsan" 2001, December 21.

[61] Ibidem, p. 136. 


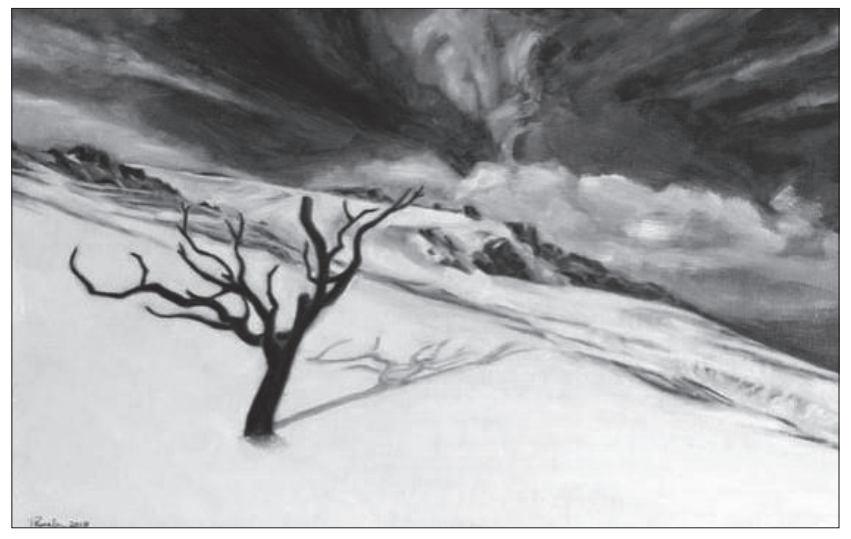

a small corner that offers the essence of the overall picture.

Levanon's landscapes of Safed are like softly-painted imaginary temples, with foundations low and high. Externally, they are realistic, but internally, they differ from reality. Using vibrant colors, the artist achieves a sense of optimism, attesting to the practical life of the present. Through the typically oriental architecture, he taps into the history of the mountain and the city. "The vertical composition creates as-

Fig. 12. Pamela Sharni, Mount Hermon (2018), oil on canvas, $70 \times 90 \mathrm{~cm}$, private collection sociations of miraculous, phenomenal events".[62] The abstract landscape becomes almost legend-like and imaginary. Safed's mountains wind devoutly as if in a Hassidic dance. "Levanon's painting is Hassidism in art; it is the sacred embodiment of 'nature' as an expression of the believer's devotion, of a soul's elevation toward the heavens".[63]

Mt. Hermon is the highest mountain cluster in Israel, located in the northern Golan Heights on its north-eastern border, along its border with Syria and Lebanon. The mountain's highest peak in the territory of Israel is 2,224 meters. The mountain became part of Israel only in the Six-Day War, but it belonged to the Jewish people in biblical times. According to some traditions, it was here that God made his covenant with Abraham, promising the land to him and his offspring. The Golan Heights and Mt. Hermon were created in a series of volcanic eruptions in ancient times, and therefore, the gigantic rocks of the Golan are made of black basaltic rock and tufa. The ferocious winds of winter help cover the mountain range with pristine snow, occasionally accompanied by heavy rains on its peak. These flow to the rivers Snir (Hatzbani), Dan, Hermon, as their tributaries flow to the Jordan River and the Sea of Galilee.

Pamela Sharni (1944) immigrated to Israel as a young woman from Columbus Ohio. She spent her youth in the dance studio and performed as a modern ballet dancer on world stages in well-known productions of the Bat Sheva Company. She also choreographed some of the works in which she performed. In the early 200os, she shed her dance shoes and embraced the brush, passionately assaulting the easel and the canvas. The same light touch, delicacy, and sensitivity that characterized her movements on stage are also reflected in her brushstrokes. The dancer of the past remained a dancer in her soul.

Pamela Sharni is a sworn nature lover who travels worldwide, covering long distances, and immortalizing landscapes through her camera lens - a talented photographer with a unique, poetic perspective. She paints sitting opposite the view or her own photographs. Her special love for forests, flowers and birds is evident in her works.
[62] T. Binyamin, L. Dorit, O. Gideon, op.cit., p. 72.
[63] Y. Keshet, Mordechai Levanon, Painter of Vision, "Meoznaim", p. 136. 
Coming upon Mount Hermon (2018) - this awe-inspiring sight of a serene white slope - the beholder is humbled and captivated by an intense sensation. The view is magnificent; the spectator, while "freezing" in the icy winds inhales the cold crisp air. The snowy winter landscape is glorious on this brilliant, sunny day, in this magical and silent setting, as the fresh snow has finished its soundless, almost clandestine, descent after the snowflakes have ceased their exhilarating performance of swirling softly as the gusts of wind change direction. Such purity of the fresh snow blanketing the earth can be felt in the air. The painting conveys a sense of tranquil beauty. It projects a mood of quiet intoxication, a sense of solitude. It is no less than a profound, uplifting religious experience. The shining whiteness of the tightly packed snow is especially emphasized by the black of the tree and rocks peeping through.

The focal point in the composition of this scene is the solitary tree and its shadow in this flow of light. The artist's poetic-expressionist touch adds to the scene by personifying the tree as an element in a dance composition. The bare tree appears to be in a dance position, with its arms drawn out to the sides or in a position of invocation, praying for the late-coming spring. Its shadow is its partner in dialogue, somewhat alleviating its loneliness.

In the background, the sky stretches in deep, bold blue, as a natural continuation of the snow covered by a thick layer of low-hanging clouds. The artist's virtuosity, handling different textures and their light reflections in a masterly fashion, is demonstrated as she captures the difference in the "feel" of the two substances - the snow and the clouds. Visual texture - the perceived surface quality of a work of art - is created by using marks to represent actual texture, creating the illusion of a texture or surface, though when touched, it would be smooth. Here, she creates two dissimilar visual surfaces, both white, by using different lines, shapes, colors or tones. Thus, one is perceived as a hard substance, while the other is soft, featherlike and somewhat ethereal.

Though the stillness in the painting is pervasive, it is dramatically dynamic. "This is what captured me" says Pamela Sharni. "The land is diagonal, and diagonal lines are unbalanced, filled with restless and uncontrolled energy appearing to be either rising or falling while conveying action and motion. Their kinetic energy and apparent movement create tension and excitement as they are more dramatic than either horizontal or vertical lines. In dance, this is known as the strongest path on stage".[64] The artist related again to her painting: "Then there is the strong vertical tree surviving the blizzard and shaped by the wind. The clouds are of different characters. The side ones create a vortex. The main one rests horizontally with an ethereal cloud rising up from it. So much is happening in this silent, mystical landscape".[65]

[64] Pamela Sharni in a private conversation. Tel Aviv, [65] Ibidem. January 30, 2018. 
Indeed, it is obvious that coupled with the serene atmosphere, the painter employed the style characterized by "implied sweeping motion used to produce an emotional tempest from a diagonal perspective".[66]

\section{Conclusion}

The Land of Israel is the Land of the Bible. Formed over 3000 years ago, its unique landscapes have shaped the life of the Jewish People throughout its history, a period during which they remained settled on the land and lived their national and cultural life as a continuum of creativity richly inspired by the sights of this Biblical land. The renewal of Jewish sovereignty over this territory has continued this tradition in the realm of artistic creation as well. All the paintings shown in this article reflect the personal interpretations that these ancient landscapes implanted in the minds of the artists, who, as mentioned, emigrated from different places to the Holy Land. The painters revitalized their works as they integrated their spiritual and sometimes mystical connection to the original landscapes of the Bible, with the contemporary panoramas. This unique, so-called phenomenon is to be found nowhere else in the world. The works related to in this article thus express an unparalleled singularity.

Article edited and sources translated by Nili Laufert

B I B L I O G R A P H Y

Agnon S., A Guest for the Night, Tel Aviv 1938

Amishai Maisels Z., Past and Present Came Together - Ardon's Work, Catalog of Ardon's 1985 exhibition, Tel Aviv 1985

Ben Ezer E., Between the Sand and the Blue Skies, Tel Aviv 1980

Ben Ezer E., Lectures in Tel Aviv, "Beit Hakibbutz Haartsi” 1992, March 24

Ben Ezer E., Nachum Guttman, Tel Aviv 1997

Binyamin T., Dorit L., Gideon O., The Story of Art in Israel, Ben Shemen 1991

Brightberg S., The National Painter, "Dapei Massa, Davar” daily newspaper, 1973, May 4

Feingersh O., Israeli Landscape (Exhibition Catalogue), Hulon 1989

Feingersh O., To Lick Fire, Retrospective Exhibition: 1964-2014, Catalog, Ra'anana: The Municipal Gallery in Beit Yad Lebanim, September 2014

Forer R., Israeli Painting: From Post Impressionism to Post Zionism, New York 1998

Gang R., "Heetamkut" March 2013, 15

Gang R., Across Nature - Silence and Infinity, Ground for Action, "Tarbut" 2002, April 26

Gang R., The Communication Channel, 2010, April

Garboz Y., [in:] Reuven Rubin - A Place, A Dream, ed. C. Rubin, Tel Aviv 2006

Giladi D., Mordechai Levanon, Artist and His Work, Jerusalem 1970

Giladi D., Tracks in Art 82 Painters in Israel, Tel Aviv 1989

Gutkind N., Nachum Guttman: The Enchanted Realist, "Hatsofeh” 1969 June 20

[66] R.L. Lewis, S.I. Lewis, The Power of Art, Belmont, CA, 2009, p. 347: "Horizontals seem calm, verticals are inspiring... both create a feeling of stasis... while strong diagonals and curves suggest movement and are energizing". 
Katz K., Interview with Modechai Ardon, “Ariel” 1963

Klimovitch T., "Haifa Weekly" 2016, August 13, <http://klim-reporter.com/20154. html>

Lewis R.L., Lewis S.I., The Power of Art, Belmont, CA, 2009

Manor D., Pink Light: Ludwig Blum's Desert Paintings, Be'er Sheva 2014

Manor D., The Painting of Ludwig Blum, Tel Aviv 2009

Maor H., MaorArt, Michael Kovner - Across the Cliff, <http://www.maorart.com/ about-4>

Meetings with a Poetess, eds R. Karton-Blum, A. Wiseman, Tel Aviv and Jerusalem 2000

Mendelson M.L., Marcel Janco, trans. V. Schwartz, Tel Aviv 1963

Ofrat G., Mordechai Levanon: The Mountain and the Palace, "Hamachsan" 2010, December 21

Ofrat G., Roots and Extraction, "Hamachsan" 2010, December 23

Ofrat G., Dorit L., The Story of Israeli Art, Ramat Gan 1991

Roth B., The Jewish Art, Tel Aviv 1956

Sallis J., Klee's Mirror, New York 2015

Schwarz A., Mordechai Ardon: The Colors of Time, Tel Aviv 2003

Tamuz B., Levita O., Ofrat G., The Story of Israeli Art: From Bezalel in 1906 to the Present, Tel Aviv 1980

Tsur U., Shuts One Eye - An Innocent Exhibition: From the Innocent Look to the Innocence in Death, "Kol Hanegev", "Ha'aretz" 2002, April 26

Yaffeh A., Marcel Janco, Tel Aviv 1982

Yellin Z., The Art of Nature: A Universal Subject, "Wildlife Art Magazine" 2005, January-February

Zalmona Y., One Hundred Years of Israeli Art, Jerusalem 2015 